Article

\title{
Investigation of synthesis and hydroisomerization performance of SAPO-11/Beta composite molecular sieve
}

\author{
Shujin Zhu a,b, Suyao Liu a,b, Huaike Zhang a,c, Enjing Lü c, Jie Ren a,c,* \\ a State key Laboratory of Coal Conversion, Shanxi Institute of Coal Chemistry, Chinese Academy of Science, Taiyuan 030001, Shanxi China \\ b University of Chinese Academy of Sciences, Beijing 10049, China \\ c National Energy Center for Coal to Liquids, Synfuels China Co., Ltd, Beijing 101400, China
}

\section{A R T I C L E I N F O}

Article history:

Received 7 March 2014

Accepted 10 April 2014

Published 20 October 2014

\section{Keywords:}

SAPO-11

Beta molecular sieve

Composite molecular sieve

Core-shell structure

Synergistic effect

Hydroisomerization

Multibranched isomers

\begin{abstract}
A B S T R A C T
The SAPO-11/Beta composite molecular sieve was synthesized by the hydrothermal method with zeolite Beta as the silicon source. The physicochemical properties of SAPO-11, Beta molecular sieve, the composite molecular sieve, and the mechanical mixture of SAPO-11 and Beta molecular sieve were characterized by X-ray diffraction, $\mathrm{N}_{2}$ adsorption-desorption, scanning electron microscopy, transmission electron microscopy-energy dispersive spectroscopy, magic-angle spinning nuclear magnetic resonance, and pyridine adsorption infrared spectroscopy. In addition, the catalytic performance of platinum-loaded zeolite samples in the hydroisomerization of $n$-dodecane was investigated. The results indicate that the properties and catalytic performance of the composite molecular sieve were quite different from those of the pure zeolites and the mechanical mixture. Compared with the mechanical mixture, the combination of SAPO- 11 and Beta by chemical bonds was more tightly bound in the composite molecular sieve with a core-shell structure. The acidity and pore structure of the composite were favorable for catalytic performance in the hydroisomerization of $n$-dodecane. The composite catalyst was superior to the other catalysts, especially in the yield of multibranched isomers.
\end{abstract}

(C) 2014, Dalian Institute of Chemical Physics, Chinese Academy of Sciences. Published by Elsevier B.V. All rights reserved.

\section{Introduction}

The skeletal isomerization of $n$-alkanes can enhance the octane number of gasoline fractions, reduce the cloud point of diesel fractions, and improve the low-temperature performance of paraffin products. As indirect coal liquefaction (Fischer-Tropsch (F-T) synthesis) in China reaches large-scale industrialization, F-T products are of interest to produce high-quality diesel oil by isomerization technology. At present, the preferred catalysts are zeolite-based. Beta [1], MOR [2], SAP0-11, SAPO-41, and ZSM-22 [3] zeolites show high activity and selectivity in the isomerization reaction of $n$-alkanes. To further improve the isomerization catalyst performance, the investiga- tion of binary carrier catalysts has attracted considerable attention [4-9]. Parton et al. [10] prepared a series of mechanical mixtures of bifunctional catalysts based on ZSM-22 and Y zeolites to investigate the synergism of ZSM-22 and Y zeolites in the bifunctional conversion of $n$-decane, and proposed the mechanism for the synergism between ZSM-22 and Y zeolites. Sun et al. [11] used $n$-hexadecane to study the isomerization performance of the mixture of SAPO-11 and Beta zeolites. The results indicated that the mixed catalyst consisting of Beta and SAP0-11 with similar acidity was favorable for the formation of multibranched isomers. Generally, the mechanical mixture will have poor connections because of the large spaces between the zeolites. However, composite molecular sieves synthesized by

\footnotetext{
* Corresponding author. Tel: +86-10-69667806; Fax: +86-10-69667803; E-mail: renjie@sxicc.ac.cn 
chemical methods not only exhibit the structural characteristics of zeolites [12], but also combine the frameworks of zeolites by chemical bonds. Composite molecular sieves have a reasonable distribution of acidity, good shape-selective performance, and hydrothermal stability, so the composite molecular sieves have potential applications in isomerization processes [13]. Liu et al [5] reported a composite zeolite catalyst $(\mathrm{Pt} / \beta-\mathrm{MCM}-41)$ and a mechanical mixture $(\mathrm{Pt} / \beta+\mathrm{MCM}-41)$ with higher activities for the hydroisomerization of $n$-heptane than $\mathrm{Pt} / \mathrm{H} \beta$. Furthermore, the isomerization selectivity of $\mathrm{Pt} / \beta-\mathrm{MCM}-41$ was superior to $\mathrm{Pt} / \beta+\mathrm{MCM}-41$.

At present, composite molecular sieves for the isomerization of long-chain alkanes have not been adequately investigated. The diffusion and reaction mechanisms of $n$-alkanes with different numbers of carbon atoms are different on the catalysts, so the chemical and physical properties of the composite molecular sieves have a great influence on the isomerization performance. Beta is a type of large-pore high-silica crystalline aluminosilicate zeolite, and is an excellent catalyst for light paraffin isomerization reactions [14,15]. Because of its medium acidity and suitable pore size, SAPO-11 shows better performance than other zeolites in lowering the pour point of diesel [16-21]. Thus, the composite molecular sieve of SAPO-11 and Beta is one of the most promising supports for bifunctional catalysts for the hydroisomerization reaction. Wang et al. [22] synthesized the H $\beta$ (core)/SAPO-11 (shell) composite molecular sieve with the hydrothermal method, in which $\mathrm{H} \beta$ was a seed for the crystallization. Zhang et al. [23] reported that the SAPO-11/Beta composite molecular sieve with a mosaic structure was synthesized in weakly alkaline conditions.

Herein, we present a method to synthesize SAPO-11 (shell)/Beta (core) composite molecular sieves in weakly acidic conditions using zeolite Beta nanoclusters as the silica source and the seed for the crystallization of the composite. For comparison, a mechanical mixture of Beta and SAPO-11 was prepared by full blending. The physicochemical properties of Beta, SAPO-11, the composite, and the mechanical mixture were characterized by X-ray diffraction (XRD), $\mathrm{N}_{2}$ adsorptiondesorption, scanning electron microscopy (SEM), transmission electron microscopy-energy dispersive spectroscopy (TEM-EDS), magic-angle spinning (MAS) nuclear magnetic resonance (NMR), and pyridine adsorption-infrared spectroscopy (Py-IR). In addition, the catalytic performances of these samples were investigated for the hydroisomerization of n-dodecane.

\section{Experimental}

\subsection{Synthesis of zeolites}

The SAP0-11/Beta composite zeolite was synthesized by the hydrothermal method. The synthesis procedure was as follows: $25 \mathrm{~g}$ Beta zeolite $\left(n\left(\mathrm{SiO}_{2}\right) / n\left(\mathrm{Al}_{2} \mathrm{O}_{3}\right)\right)=20$, Catalyst Plant of Nankai University, Tianjin, China) was added to $40 \mathrm{~mL}$ of distilled water and the mixture was stirred for $30 \mathrm{~min}$ with $\mathrm{pH}$ = 8.0. $\mathrm{H}_{3} \mathrm{PO}_{4}$ (85 wt\%, Sinopharm Co., Shanghai, China), pseudoboehmite (70 wt\% $\mathrm{Al}_{2} \mathrm{O}_{3}$, Chinalco, Beijing, China), and dis- tilled water was mixed and stirred for $10 \mathrm{~min}$. The above slurries were mixed with hybrid template, which was a mixture of di- $n$-propylamine and di-iso-propylamine $\left(m_{\text {DPA }}: m_{\text {DIPA }}=1, \mathrm{Si}-\right.$ nopharm Co., Shanghai, China), and stirred for $0.5 \mathrm{~h}$ to form a homogeneous slurry with $\mathrm{pH}=6.0$. The gel was moved to autoclaves with capacity $2 \mathrm{~L}$ and heated at $200{ }^{\circ} \mathrm{C}$ for $24 \mathrm{~h}$. After crystallization, the products were washed, dried at $120{ }^{\circ} \mathrm{C}$ overnight, and then calcined at $550{ }^{\circ} \mathrm{C}$ for $15 \mathrm{~h}$ to completely remove the template. This product was SAPO-11/Beta.

The mechanical mixture of SAPO-11 + Beta was prepared by blending Beta with SAPO-11 ( $m_{\text {Beta: }} m_{\mathrm{SAPO}-11}=3: 17$ ). SAPO-11 was synthesized in accordance with the literature with some modification $[24,25] . \mathrm{H}_{3} \mathrm{PO}_{4}$ (85 wt\%, Sinopharm Co., Shanghai, China), pseudoboehmite (70 wt $\% \mathrm{Al}_{2} \mathrm{O}_{3}$, Chinalco, Beijing, China) and distilled water were mixed and stirred for $10 \mathrm{~min}$. Silica sol and hybrid template were then successively added. The mixture was stirred for $0.5 \mathrm{~h}$ at $\mathrm{pH}=6.0$. The crystallization process and post-treatment of SAPO- 11 were the same as that of composite zeolite.

The weight fraction of SAPO-11 in the composite and the mechanical mixture was estimated from a plot of the XRD peak intensity of SAPO-11 $\left(2 \theta=23.3^{\circ}\right)$ versus weight fraction of SAPO-11. The plot was obtained by correlating the relationship of the XRD peak intensity of SAPO-11 $\left(2 \theta=23.3^{\circ}\right)$ with the known SAPO-11 weight fraction in the mixture of SAPO-11 with Beta prepared by the mechanical blending method.

\subsection{Preparation of catalysts}

Dilute nitric acid was added into a mixture of the molecular sieve and $\mathrm{Al}_{2} \mathrm{O}_{3}$ with mass ratio 9 , which was extruded to the carrier. The catalysts of $0.5 \mathrm{wt} \%$ Pt-loaded zeolite carriers were prepared by the wet impregnation method with $\mathrm{H}_{2} \mathrm{PtCl}_{6}$ solutions for the metal precursor. The catalysts were dried at $120{ }^{\circ} \mathrm{C}$ and then calcined at $450{ }^{\circ} \mathrm{C}$ for $4 \mathrm{~h}$.

\subsection{Characterization}

Powder XRD patterns were collected using a Bruker AXS-D8 powder X-ray diffractometer with $\mathrm{Cu} K_{\alpha}$ radiation $(0.154 \mathrm{~nm})$ at $30 \mathrm{kV}$ and $10 \mathrm{~mA}$ in the scan range $5^{\circ}$ to $50^{\circ}$. SEM was performed with a Quanta 400F scanning electron microscope (FEI, Eindhoven, The Netherlands). The morphology and chemical composition of the composite were determined by TEM (Tecnai $^{\mathrm{TM}} \mathrm{G}^{2}$ F30, FEI) combined with EDS. $\mathrm{N}_{2}$ adsorption-desorption was measured on a Micromeritics ASAP 2420. Prior to the measurements, the sample (about $200 \mathrm{mg}$ ) was outgassed under vacuum at $350{ }^{\circ} \mathrm{C}$ for $8 \mathrm{~h}$. The surface area was calculated according to the Brunauer-Emmett-Teller (BET) method and the volume of pores was obtained by $t$-plot analysis. The ${ }^{29} \mathrm{Si},{ }^{27} \mathrm{Al}$, and ${ }^{31} \mathrm{P}$ MAS NMR spectra were recorded on a Bruker AvanceIIIT 600 spectrometer with frequencies of 119.2, 156.4, and $242.9 \mathrm{MHz}$, respectively. The ${ }^{29} \mathrm{Si}$ MAS NMR spectra were acquired using a 7-mm probe with a rotor spinning rate of $5 \mathrm{kHz}$. The ${ }^{27} \mathrm{Al}$ MAS NMR and ${ }^{31} \mathrm{P}$ MAS NMR spectra were measured using a 4-mm probe with a spinning speed of $13 \mathrm{kHz}$. The Py-IR spectra were recorded with a Bruker Ver- 
tex 70 FTIR spectrometer. The catalyst samples were ground into a fine powder and pressed into self-supported discs with ZnSe windows. The sample discs were heated to $400{ }^{\circ} \mathrm{C}$ and kept for $3 \mathrm{~h}$ under vacuum. He flow saturated with pyridine was then introduced into the IR cell at room temperature until adsorption saturation of the samples. The Py-IR spectra were recorded at 150 and $300^{\circ} \mathrm{C}$.

\subsection{Catalytic test}

The catalytic performance of the samples in the hydroisomerization reaction was tested in a continuous down-flow fixed-bed reactor. The catalysts were reduced in situ in a flow of $\mathrm{H}_{2}$ at $400{ }^{\circ} \mathrm{C}$ for $4 \mathrm{~h}$ prior to the reaction. The reaction conditions were as follows: $n$-dodecane with liquid hourly space velocity (LHSV) 2.0, $\mathrm{H}_{2} / n$-dodecane molar ratio 2 , pressure $2.0 \mathrm{MPa}$, temperature $240-360{ }^{\circ} \mathrm{C}$. The liquid products were collected after condensation and analyzed by a gas chromatograph (Agilent 6890N) equipped with OV-101 capillary column. The gas-phase product analysis was carried out on-line with a gas chromatograph (Agilent 6890N) equipped with HP-MoleSieve5A (30 $\mathrm{m} \times 0.53 \mathrm{~mm})$ and HP-Plot $\mathrm{Al}_{2} \mathrm{O}_{3}(30 \mathrm{~m} \times 0.53 \mathrm{~mm})$. The material balance calculation shows that $>95 \%$ of the feed was recovered as product.

We used the related physical quantities defined as follows.

The conversion of $n$-dodecane:

Conversion $(\%)=\frac{(n \text {-dodecane })_{\text {feed }}-(n \text {-dodecane })_{\text {effluent }}}{(n \text {-dodecane })_{\text {feed }}} \times 100$

The percentage yield of a particular product fraction $i$ :

$$
\text { Yield }(\%)=\frac{(i)_{\text {effluent }}}{(n \text {-dodecane })_{\text {feed }}} \times 100
$$

Here, ( $n$-dodecane) feed and ( $n$-dodecane) $)_{\text {effluent }}$ are the mass concentrations of dodecane in the feed and effluent, respectively, and $(i)_{\text {effluent }}$ is the mass concentration of product $i$ in the effluent.

\section{Results and discussion}

\subsection{Characterization}

\subsection{1. $X R D$}

Figure 1 shows the XRD patterns of SAPO-11, Beta, SAPO-11/Beta, and SAPO-11 + Beta. The XRD pattern of SAPO-11/Beta shows all the diffraction peaks of both SAPO-11 and Beta without any other diffraction peaks. This indicates that SAPO-11/Beta could be synthesized by the hydrothermal method. The weak diffraction peak at $7.5^{\circ}$ in the SAPO-11/Beta pattern indicates that the Beta content was low. The contents of SAPO-11 in SAPO-11/Beta and SAPO-11 + Beta are shown in Table 1.

\subsection{2. $N_{2}$ adsorption-desorption}

Figure 2 shows the $\mathrm{N}_{2}$ adsorption-desorption isotherms of SAPO-11, Beta, SAPO-11/Beta, and SAPO-11 + Beta. Monolayer adsorption occurred on all the samples at low pressure, so the isotherms had shapes that are characteristic of microporous networks [26]. The adsorption-desorption isotherms of

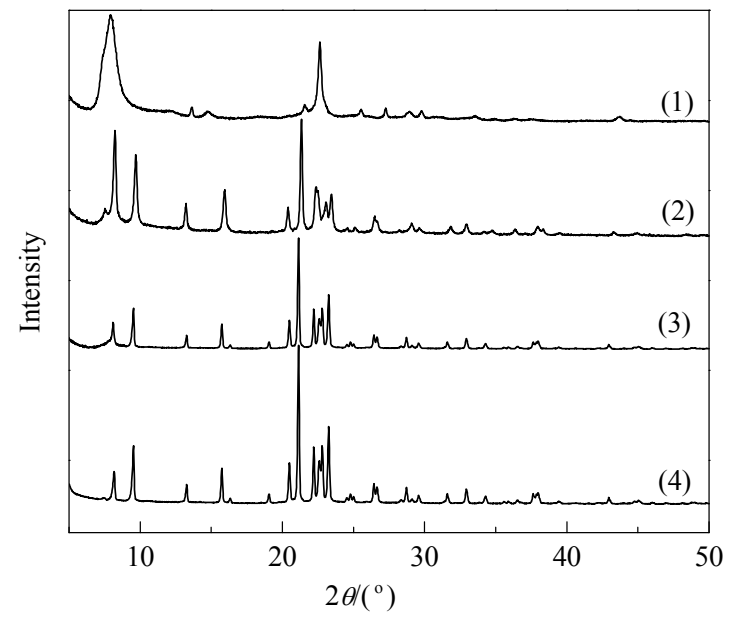

Fig. 1. XRD patterns of the samples. (1) Beta; (2) SAPO-11/Beta; (3) SAPO-11+Beta; (4) SAPO-11.

Table 1

Textural properties of the samples.

\begin{tabular}{|c|c|c|c|c|c|}
\hline \multirow{2}{*}{ Sample } & \multirow{2}{*}{$\begin{array}{c}\text { SAPO-11 } \\
\text { (wt } \% \text { ) }\end{array}$} & \multicolumn{3}{|c|}{$A_{\mathrm{BET}} /\left(\mathrm{m}^{2} / \mathrm{g}\right)$} & \multirow{2}{*}{$\frac{V_{\text {BET }} /\left(\mathrm{cm}^{3} / \mathrm{g}\right)}{\text { Micropore }}$} \\
\hline & & Micropore & External & Total & \\
\hline SAPO-11/Beta & 85 & 180.4 & 50.5 & 230.9 & 0.089 \\
\hline SAPO-11+Beta & 85 & 204.9 & 43.5 & 248.4 & 0.101 \\
\hline Beta & - & 257.3 & 118.3 & 375.6 & 0.130 \\
\hline SAPO-11 & - & 169.7 & 39.1 & 208.8 & 0.035 \\
\hline
\end{tabular}

SAPO-11 + Beta and SAPO-11/Beta were between the isotherms of SAPO-11 and Beta, indicating that both were a mixture of SAPO-11 and Beta. Furthermore, the SAPO-11/Beta isotherm was different to the SAPO-11 + Beta isotherm. This indicates that the combination mode of SAPO-11 and Beta in SAPO-11/Beta was different to that in SAPO-11 + Beta.

From Table 1, the BET areas ( A $\left._{\mathrm{BET}}\right)$ of SAPO-11 + Beta and SAPO-11/Beta were between those of SAPO-11 and Beta. SAPO-11/Beta had a lower surface area than SAPO-11 + Beta. In addition, the microporous BET area of SAPO-11 (144.2 m²/0.85 g) plus that of Beta $\left(38.6 \mathrm{~m}^{2} / 0.15 \mathrm{~g}\right)$ was equal to $182.8 \mathrm{~m}^{2} / \mathrm{g}$, which is close to that of SAPO-11/Beta $\left(180.4 \mathrm{~m}^{2} / \mathrm{g}\right)$. There-

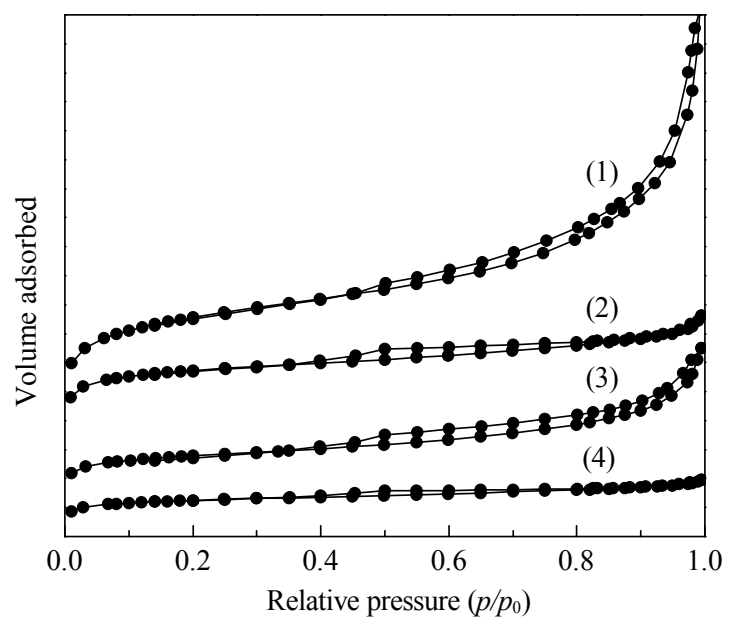

Fig. 2. $\mathrm{N}_{2}$ adsorption-desorption isotherms of the samples. (1) Beta; (2) SAPO-11 + Beta; (3) SAPO-11/Beta; (4) SAPO-11. 
fore, the channels of Beta in SAPO-11/Beta were not blocked after the addition of SAPO-11 during the synthesis of SAPO-11/Beta.

\subsubsection{SEM and TEM-EDS}

Figure 3 shows the SEM images of Beta, SAPO-11, SAPO-11/Beta, and SAPO-11 + Beta. There is an obvious difference in the morphology and particle size of the samples. The particle size of Beta ranged from 0.4 to $0.5 \mu \mathrm{m}$. SAPO- 11 was composed of uniform cubic particles with particle size of $c a 4 \mu \mathrm{m}$. The image of SAPO-11 + Beta showed a mixture of spherical Beta and cubic SAPO-11 particles. However, the micrograph of SAPO-11/Beta showed pseudo-spherical aggregates accumulated with columnar crystals without single SAPO-11 or Beta particles, and the particle size was $c a .5 \mu \mathrm{m}$. It has been suggested that SAPO-11 may grow around the undissolved Beta zeolite, forming a SAPO-11 (shell)/Beta (core) structure [27]. These results indicate that Beta and SAPO-11 were combined more tightly in SAP0-11/Beta than in SAPO-11 + Beta. Furthermore, more external surface area was formed owing to the increased interspaces between the SAPO-11 and Beta particles in SAP0-11/Beta [28], which was confirmed by the BET results.

The TEM-EDS analysis results of SAPO-11/Beta are shown in Fig. 4 and Table 2. From Fig. 4(a), the micrograph of SAPO-11/Beta showed rectangularly packed pseudo-spherical aggregates. This can be seen more clearly in the micrograph of Fig. 4(b). Table 2 shows the chemical composition of SAPO-11/Beta from EDS. For the outside (shell) of SAPO-11/ Beta (1\#), the contents of $\mathrm{Si}, \mathrm{Al}$, and $\mathrm{P}$ were approximately the same as SAPO-11. The $n\left(\mathrm{SiO}_{2}\right) / n\left(\mathrm{Al}_{2} \mathrm{O}_{3}\right)$ ratio of SAPO-11/Beta was more than double that of SAPO-11. These results confirmed that SAP0-11/Beta was made up of SAPO-11 (shell) and Beta (core).

\subsubsection{Solid-state MAS NMR}

Figure 5 and Table 3 show the ${ }^{29} \mathrm{Si}$ MAS NMR results of the

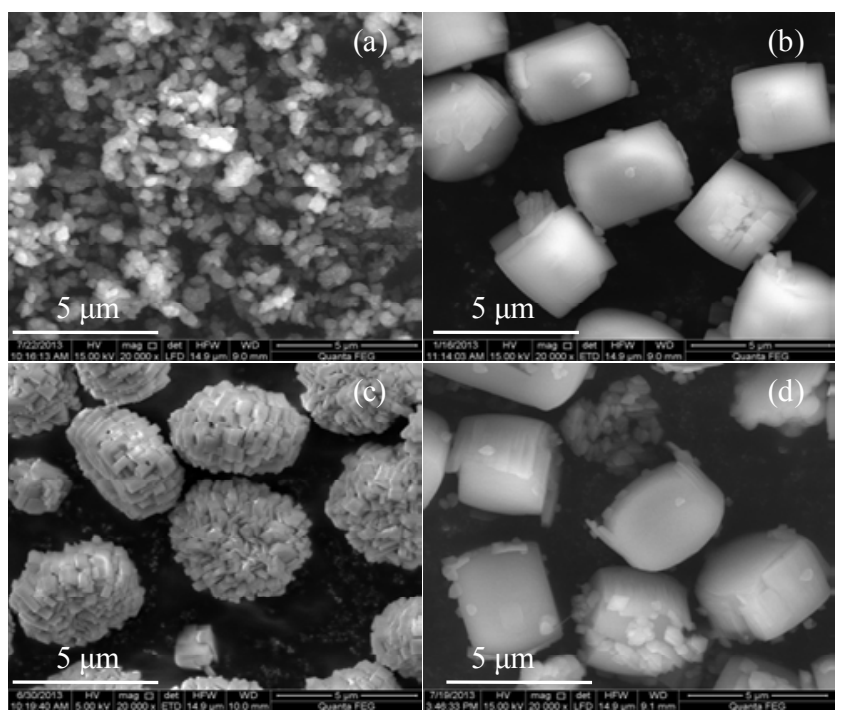

Fig. 3. SEM images of the samples. (a) Beta; (b) SAPO-11; (c) SAPO11/Beta; (d) SAPO-11 + Beta.

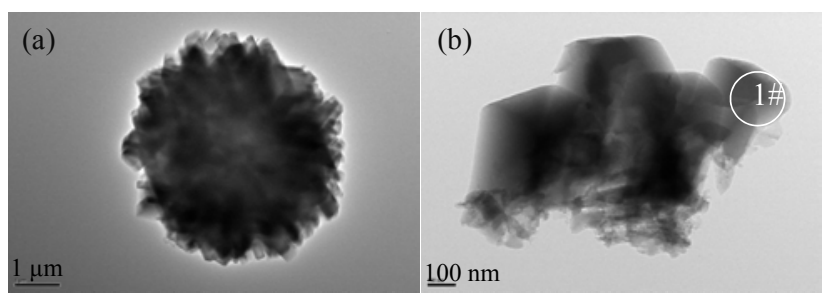

Fig. 4. TEM images of SAPO-11/Beta.

Table 2

Chemical composition of the samples (TEM-EDS).

\begin{tabular}{lcc}
\hline Sample & $n\left(\mathrm{SiO}_{2}\right) / n\left(\mathrm{Al}_{2} \mathrm{O}_{3}\right)$ & $n\left(\mathrm{P}_{2} \mathrm{O}_{5}\right) / n\left(\mathrm{Al}_{2} \mathrm{O}_{3}\right)$ \\
\hline SAPO-11/Beta & 0.35 & 0.99 \\
Beta & 28.5 & - \\
SAPO-11 & 0.10 & 1.05 \\
1\# & 0.09 & 1.07 \\
\hline
\end{tabular}

solid samples. In the ${ }^{29} \mathrm{Si}$ MAS NMR spectra, the resonance peaks at -86 and -91 were assigned to the $\mathrm{Si}(0 \mathrm{Si})$ environment of SAPO, and the resonance peaks at $-97,-102,-107$, and $-110 /-116$ corresponded to the $\mathrm{Si}(1 \mathrm{Si}), \mathrm{Si}(2 \mathrm{Si}), \mathrm{Si}(3 \mathrm{Si})$, and $\mathrm{Si}(4 \mathrm{Si})$ environments, respectively [29-32]. From the ${ }^{29} \mathrm{Si}$ MAS NMR spectra of the different samples, the Si chemical environments of SAP0-11/Beta were different with those of SAPO-11 + Beta. The low silicon content of SAPO-11 led to the weak resonance peaks of $\mathrm{Si}(n \mathrm{Al})(n=1-3)$, so SAPO-11 + Beta and Beta have similar ${ }^{29} \mathrm{Si}$ MAS NMR spectra. The ${ }^{29} \mathrm{Si}$ MAS NMR spectrum of SAPO-11/Beta showed a broad band in the range -115

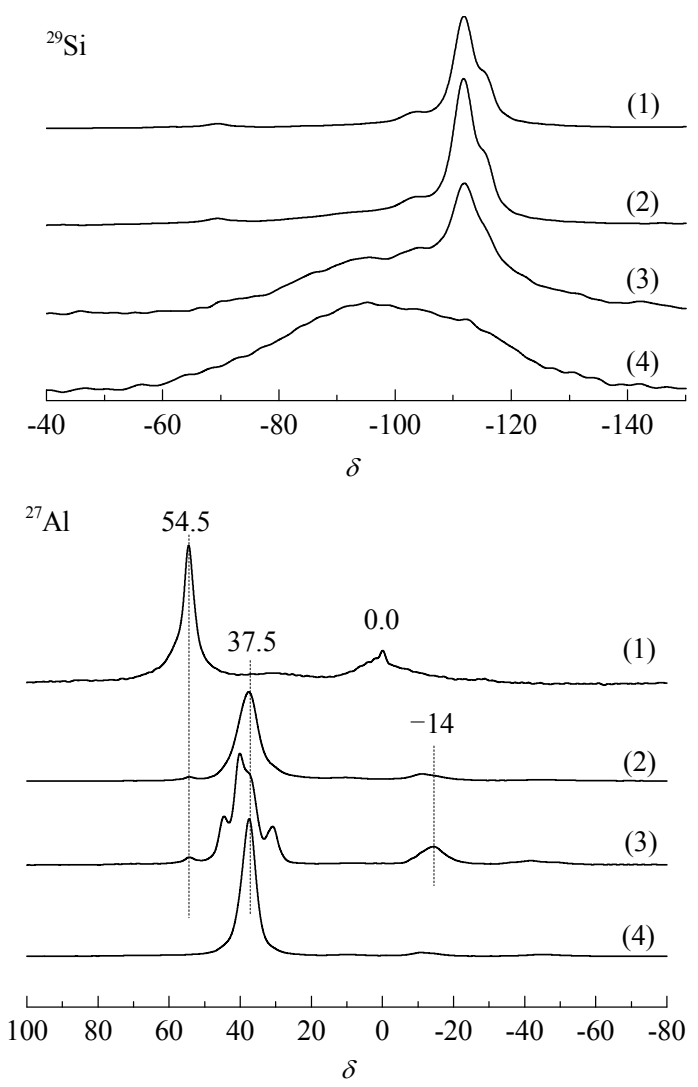

Fig. 5. ${ }^{29} \mathrm{Si}$ and ${ }^{27} \mathrm{Al}$ MAS NMR spectra of the samples. (1) Beta; (2) SAPO-11 + Beta; (3) SAPO-11/Beta; (4) SAPO-11. 
Table 3

Deconvolution of the ${ }^{29} \mathrm{Si}$ MAS NMR spectra of the samples.

\begin{tabular}{lccccc}
\hline Sample & $\mathrm{Si}(0 \mathrm{Si})$ & $\mathrm{Si}(1 \mathrm{Si})$ & $\mathrm{Si}(2 \mathrm{Si})$ & $\mathrm{Si}(3 \mathrm{Si})$ & $\mathrm{Si}(4 \mathrm{Si})$ \\
& $-86 /-90$ & -96 & -102 & -107 & $-110 /-116$ \\
\hline Beta & 0 & 0 & 16.6 & 20.5 & 62.9 \\
SAP0-11 & 37.7 & 13.4 & 16.5 & 13.2 & 19.2 \\
SAP0-11 + Beta & 5.9 & 3.9 & 10.2 & 11.2 & 68.8 \\
SAP0-11/Beta & 18.7 & 17.1 & 15 & 14.1 & 35.1 \\
\hline
\end{tabular}

to -86. Compared with SAPO-11 + Beta, SAPO-11/Beta had more $\mathrm{Si}$ species of $\mathrm{Si}(n \mathrm{Al})(n=1-3)$. From the ${ }^{27} \mathrm{Al}$ MAS NMR spectra, SAPO-11/Beta and SAPO-11 + Beta showed two signals at 37.5 and 54.5 , which originated from the resonances of tetrahedral aluminum in the framework of SAPO-11 and Beta, respectively [23]. Generally, the chemical shifts of tetrahedral aluminum in microporous aluminophosphate materials are about 40 [33]. The three peaks in the ${ }^{27} \mathrm{Al}$ MAS NMR spectrum of SAPO-11/Beta indicate that the $\mathrm{Al}$ atoms have complex coordination environments, which is possibly because of the presence of defect structures in the framework of SAPO-11 with Beta. Moreover, the broad signal at -14 was attributed to the presence of extra-framework aluminum. In addition, the content of extra-framework aluminum in SAPO-11/Beta was clearly more than in SAPO-11 + Beta.

Figure 6 shows that the 31P MAS NMR spectra of SAPO-11, SAPO-11 + Beta, and SAPO-11/Beta. SAPO-11 and SAPO-11 + Beta have two signals at -30.7 , which originate from the resonance of tetrahedral phosphorous in the framework [34]. SAP0-11/Beta not only showed the signal at -30.1 , but also showed a new signal at -22.5 owing to the presence of extra-framework aluminophosphate [23,35].

\subsubsection{Acidity characterization}

The acidity of Pt-Beta, Pt-SAPO-11, Pt-SAPO-11/Beta and Pt-SAPO-11 + Beta was investigated by Py-IR. The density and distribution of acid sites were estimated according to the areas of the corresponding IR bands. The results are summarized in Table 4. The weak acid sites, strong acid sites, total acid sites, and the density of $\mathrm{B}$ acid sites decreased in the order Pt-Beta > Pt-SAPO-11 + Beta > Pt-SAPO-11/Beta > Pt-SAP0-11. $(\mathrm{B}+$ L) $150 /(B+L)_{300}$ was used to characterize the distribution of weak and strong acid sites. From the $(B+L)_{150} /(B+L)_{300}$ values (Table 4), the four catalysts have more weak acid sites than strong acid sites. The order of $(B+L)_{150} /(B+L)_{300}$ was as follows: Pt-SAPO-11/Beta > Pt-SAPO-11 > Pt-SAPO-11 + Beta > Pt-Beta. Pt-SAPO-11/Beta had the highest $\mathrm{B}_{150} / \mathrm{L}_{150}, \mathrm{~B}_{300} / \mathrm{L}_{300}$, and $B_{\text {total }} / L_{\text {total }}$ values of the investigated samples, indicating that the catalyst of the composite molecular sieve had the

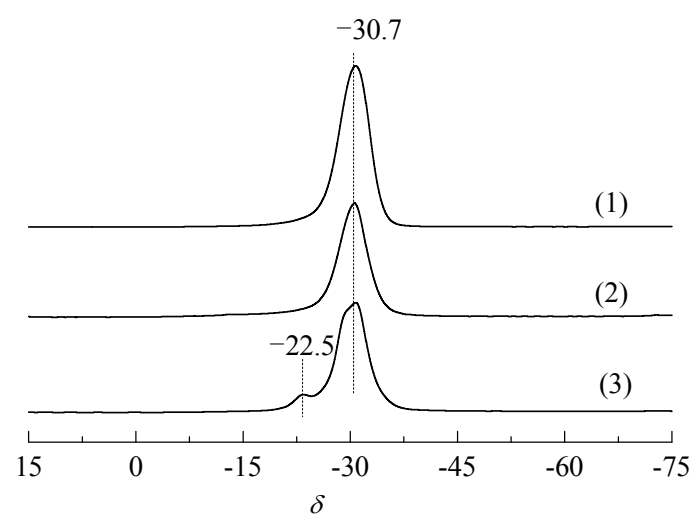

Fig. 6. ${ }^{31}$ P MAS NMR spectra of the samples. (1) SAPO-11; (2) SAP0-11 + Beta; (3) SAPO-11/Beta.

highest distribution of B acid sites.

The presence of defect structures in the framework and the formation of extra-framework aluminophosphate demonstrated that the SAPO-11 and Beta frameworks combined by chemical bonds in SAPO-11/Beta. Thus, Pt-SAPO-11/Beta had a different density and distribution of acid sites to Pt-SAPO-11 + Beta. The B/L ratio of Pt-SAPO-11/Beta was higher than the $\mathrm{B} / \mathrm{L}$ ratios of the other catalysts. Pt-SAPO-11/Beta had a different acidity from the other catalysts. This confirmed that the framework of SAPO-11 and Beta was combined by chemical bonds in SAPO-11/Beta.

\subsection{Hydroisomerization performance of the catalysts}

Figure 7 shows the conversion of $n$-dodecane over Pt-Beta, Pt-SAPO-11, Pt-SAPO-11 + Beta, and Pt-SAPO-11B catalysts. The conversion of $n$-dodecane measured over the different catalysts decreased in the order Pt-Beta $>$ Pt-SAPO-11 + Beta > Pt-SAPO-11/Beta > Pt-SAPO-11. This order is the same as that of the total amount of acid $[14,36]$.

The yield of isomers over the four catalysts is shown in Fig. 8. Pt-SAPO-11/Beta had the highest isomer yield. Pt-SAPO-11 + Beta had an intermediate isomer yield to the yields of the pure zeolite catalysts.

Höchtl et al. [37] concluded that loading of $0.5 \mathrm{wt} \% \mathrm{Pt}$ in a bifunctional catalyst could meet the requirement for the hydrogenation-dehydrogenation function. In the isomerization reaction, when the hydrogenating function is highly active, the catalytic performance depends on the $\mathrm{B}$ acid sites $[8,38]$. The isomer yield increased with increasing $\mathrm{B} / \mathrm{L}$ ratio, in agreement with the results of Py-IR, indicating that the distribution of $B$

Table 4

Acidity properties of samples determined by Py-IR characterization.

\begin{tabular}{|c|c|c|c|c|c|c|c|c|c|c|}
\hline \multirow{3}{*}{ Sample } & \multicolumn{6}{|c|}{ Acidity $(\mu \mathrm{mol} \mathrm{Py} / \mathrm{g})$} & \multirow{2}{*}{\multicolumn{4}{|c|}{ Distribution of acid sites }} \\
\hline & \multicolumn{2}{|c|}{$150^{\circ} \mathrm{C}$} & \multicolumn{2}{|c|}{$300^{\circ} \mathrm{C}$} & \multicolumn{2}{|c|}{ Total } & & & & \\
\hline & $\mathrm{L}$ & $\mathrm{B}$ & $\mathrm{L}$ & $\mathrm{B}$ & $\mathrm{L}$ & $\mathrm{B}$ & $(B+L)_{150} /(B+L)_{300}$ & $\mathrm{~B}_{150} / \mathrm{L}_{150}$ & $\mathrm{~B}_{300} / \mathrm{L}_{300}$ & $\mathrm{~B}_{\text {total}} / \mathrm{L}_{\text {total }}$ \\
\hline Pt-Beta & 141.4 & 90.7 & 107 & 64 & 248.4 & 154.7 & 1.36 & 0.64 & 0.60 & 0.62 \\
\hline Pt-SAPO-11 & 15.9 & 21.8 & 11.3 & 14.9 & 27.2 & 36.7 & 1.44 & 1.37 & 1.32 & 1.35 \\
\hline Pt-SAPO-11/Beta & 39.7 & 54.7 & 19.7 & 33.9 & 59.4 & 88.6 & 1.76 & 1.38 & 1.72 & 1.49 \\
\hline Pt-SAP0-11 + Beta & 48 & 43.7 & 26.4 & 37.9 & 74.3 & 81.7 & 1.43 & 0.91 & 1.44 & 1.10 \\
\hline
\end{tabular}




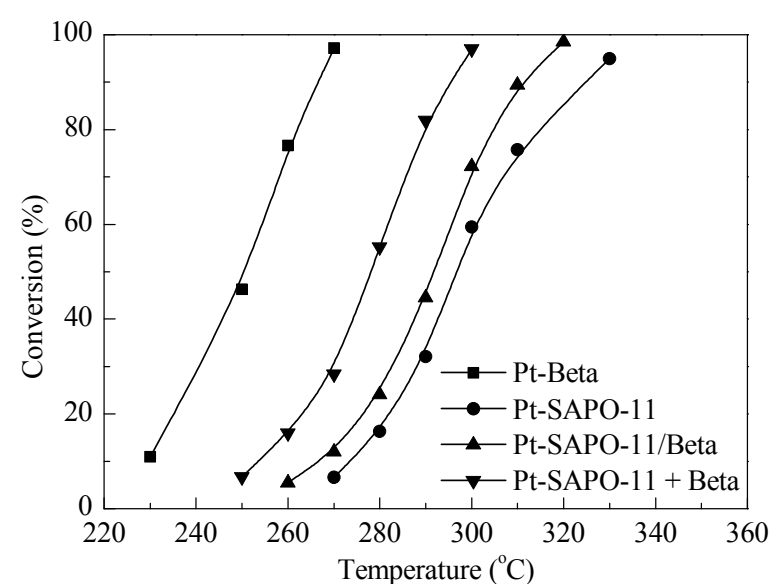

Fig. 7. Hydroisomerization of $n$-dodecane as a function of temperature over the different catalysts.

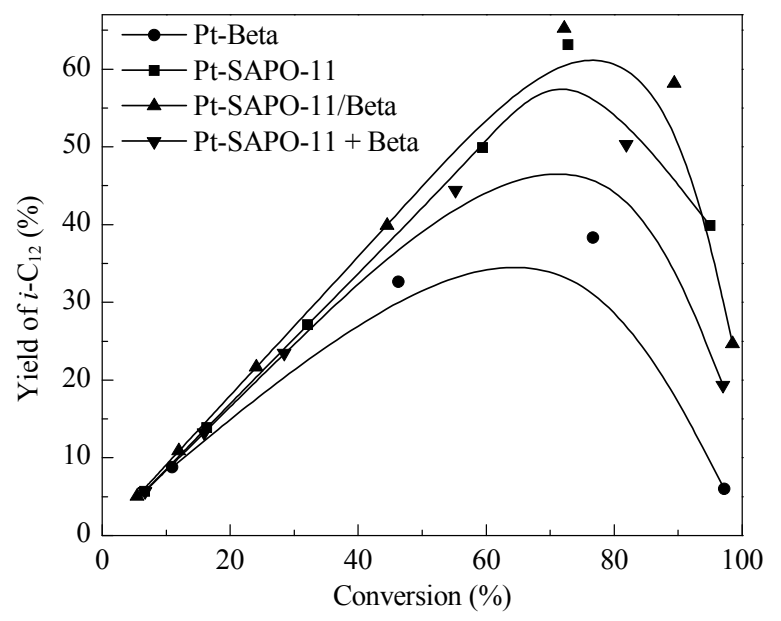

Fig. 8. Yield of the isomers against conversion of $n$-dodecane.

acid sites over the bifunctional catalyst had a great influence on the hydroisomerization performance of $n$-dodecane. The Pt-SAPO-11/Beta catalyst, which had the highest number of B acid sites and $\mathrm{B} / \mathrm{L}$ ratio, gave the highest isomer yield in the hydroisomerization of $n$-dodecane. Compared with Pt-SAP0-11/Beta, Pt-SAPO-11 + Beta had higher conversion of $n$-dodecane at the same reaction temperature owing to the larger total number of acid sites. However, the isomers were easily cracked into small molecules on the strong acid sites of Pt-SAPO- $11+$ Beta $\left(300^{\circ} \mathrm{C}\right)$, and thus the yield of isomers decreased.

Claude et al. [39] investigated long-chain alkane hydroisomerization over Pt/HZMS-22. The results indicated that short alkanes such as decane and undecane were mainly converted by pore mouth mechanisms, while for dodecane and larger alkanes the contribution of key-lock mechanisms increases with increasing carbon number. In addition, pore mouth mechanisms favored branching at the end position over medium pore zeolite catalysts. As shown from Figure 5, the hydroisomerization reaction of $n$-dodecane was mainly by pore mouth mechanisms over Pt-SAPO-11. Pt-SAPO-11 + Beta and Pt-SAPO-11/Beta gave quite different distributions of mono-
Table 5

Distribution of monobranched isomers obtained by the isomerization of dodecane.

\begin{tabular}{lcccc}
\hline \multirow{2}{*}{$\begin{array}{l}\text { Monobranched } \\
\text { isomers }\end{array}$} & \begin{tabular}{c} 
Pt- \\
\cline { 2 - 5 }
\end{tabular} & $\begin{array}{c}\text { Pt-SAPO- } \\
\end{array}$ & $\begin{array}{c}\text { Pt-SAPO-11/ } \\
\text { Beta }\end{array}$ & $\begin{array}{c}\text { Pt-SAPO-11 + } \\
\text { Beta }\end{array}$ \\
\hline 2-metyl undecane & 15.38 & 31.34 & 1.96 & 2.29 \\
3-metyl undecane & 24.07 & 21.94 & 22.56 & 23.09 \\
4-metyl undecane & 20.96 & 16.69 & 17.00 & 20.73 \\
5-metyl undecane & 37.90 & 28.65 & 21.14 & 19.72 \\
6-metyl undecane & 1.69 & 1.39 & 37.35 & 34.17 \\
\hline Reaction conditions: $T=270^{\circ} \mathrm{C}, P=2.0 \mathrm{MPa}, \mathrm{LHSV}=2.0 \mathrm{~h}^{-1}$.
\end{tabular}

branched isomers to the pure zeolite catalysts. Isomers with branching at the $\mathrm{C}_{2}$ position were rarely detected over the binary carrier catalysts, which favored $\mathrm{C}_{5}$ and $\mathrm{C}_{6}$ isomers in monobranched isomers. Thus, the hydroisomerization reaction of $n$-dodecane was mainly by the key-lock mechanism over the binary carrier catalysts.

The relationship between the yield of multibranched isododecanes and dodecane conversion is shown in Figure 9. The yields of multibranched isomers over the binary carrier catalysts were higher than those over the pure zeolite catalysts. This indicates that synergism of Beta and SAPO-11 existed in bifunctional conversion of $n$-dodecane over the composite or mechanical mixture catalyst. The hydroisomerization reaction of $n$-dodecane was mainly by the key-lock mechanism over the binary carrier catalysts. The alkanes were adsorbed on the surface of the catalyst, and then the two ends of the hydrocarbon chain penetrated into a different pore opening, resulting in the formation of more multibranched isomers. Furthermore, the yield of multibranched isomers over Pt-SAPO-11/Beta was higher than that over Pt-SAPO-11 + Beta. The core-shell structure of SAPO-11/Beta differs from the independent structures of SAPO-11 and Beta in SAPO-11 + Beta. Compared with SAPO-11 + Beta, the smaller spacing of SAPO-11 and Beta in SAP0-11/Beta was more favorable for conversion by the key-lock mechanism and migration of the multibranched isomers. On the other hand, Pt-SAPO-11 + Beta has many strong acid sites $\left(300^{\circ} \mathrm{C}\right)$, which result in the multibranched interme-

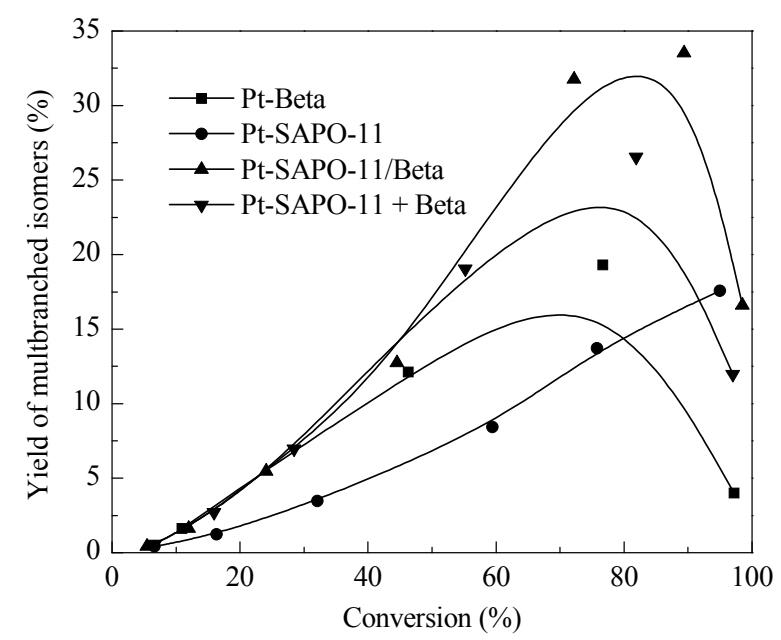

Fig. 9. Yield of the multibranched isomers against conversion of $n$-dodecane. 
diates cracking into small molecules. However, owing to the combination of SAPO-11 and Beta with chemical bonds, the composite molecular sieve had an appropriate number of $\mathrm{B}$ acid sites and acid distribution. Thus, a higher multibranched isomer yield was obtained over Pt-SAPO-11/Beta.

\section{Conclusions}

The SAPO-11/Beta composite molecular sieve was synthesized by the hydrothermal method using zeolite Beta as the silica source The close combination of the Beta and SAPO-11 forms resulted in many $\mathrm{Si}$ species of $\mathrm{Si}(n \mathrm{Al})(n=1-3)$ and extra-framework aluminum atoms, which led to the composite molecular sieve having more weak acid and B acid sites. Compared with the single and mechanically mixed molecular sieve catalysts, $n$-dodecane hydroisomerization over the Pt-SAPO11 /Beta catalyst gave the highest yield of multibranched isomers. The yield of multibranched isomers reached a maximum value of $34 \%$ at $89 \%$ conversion on Pt-SAPO-11/Beta.

\section{Acknowledgments}

We thank the support of technology and equipment from Synfuels China Co. Ltd.

\section{References}

[1] Chao K J, Wu H C, Leu L J. Appl Catal A, 1996, 143: 223

[2] Eswaramoorthi I, Geetha Bhavani A, Lingappan N. Appl Catal A, 2003, 253: 469

[3] Nghiem V T, Sapaly G, Mériaudeau P, Naccache C. Top Catal, 2001, 14: 131

[4] Elangovan S P, Hartmann M. J Catal, 2003, 217: 388
[5] Liu P, Yao Y, Wang J. Reac Kinet Mech Catal, 2010, 101: 465

[6] Zhang A H, Nakamura I, Aimoto K, Fujimoto K. Ind Eng Chem Res, 1995, 34: 1074

[7] Kingeretal G, Majdal D, Vinek H. Appl Catal A, 2002, 225: 301

[8] Kusakari T, Tomishige K, Fujimoto K. Appl Catal A, 2002, 224: 219

[9] Miller S J. US Patent 5149421.1992

[10] Parton R, Uytterhoeven L, Martens J A, Jacobs P A, Froment G F. Appl Catal A, 1991, 76: 131

[11] Sun X, Huang W G, Kang X H. Petrol Process Petrochem (孙霞, 黄 卫国, 康小洪. 石油炼制与化工), 2010, 41(6): 1

[12] Fan Y, Lei D, Shi G, Bao X J. Catal Today, 2006, 114: 388

[13] Wang B, Zhang X W, Ma B, Zhang Z. Contemporary Chem Ind (王博, 张喜文, 马波, 张志智. 当代化工), 2009, 38: 412

[14] Roldán R, Romero F J, Jiménez-Sanchidrián C,Marinas J M, Gómez J P. Appl Catal A, 2005, 288: 104

[15] Chao K J, Lin C C, Lin C H, Wu H C, Tseng C W, Chen S H. Appl Catal A, 2000, 203: 211

[16] Zhang S Z, Chen S L, Dong P, Ji Z Y, Zhao J Y, Xu K Q. Chin J Catal (张 胜振, 陈胜利, 董鹏, 纪智勇, 赵俊颖, 徐克琪. 催化学报), 2007, 28: 857

[17] Liu P, Ren J, Sun Y H. Chin J Catal (刘平, 任杰, 孙予罕. 催化学报), 2008, 29: 379

[18] Guo L, Fan Y, Bao X J, Shi G, Liu H Y. J Catal, 2013, 301: 162

[19] Hu Y F, Wang X S, Guo X W, Li S L, Hu S, Sun H B, Bai L. Catal Lett, 2005, 100: 59

[20] Meriaudeau P, Tuan V A, Nghiem V T, Lai S Y, Hung L N, Naccache C. J Catal, 1997, 169: 55

[21] Huang W G, Li D D, Shi Y H, Kang X H, Meng X B, Wang K, Dong W Z, Nie H, Li C. Chin J Catal (黄卫国, 李大东, 石亚华, 康小洪, 孟宪 波, 王奎, 董维正, 聂红, 李灿. 催化学报), 2003, 24: 651

[22] Wang X X, Guo Sh Q, Zhao L F, Bull Korean Chem Soc, 2013, 34: 3829

[23] Zhang X, Wang J W, Zhong J, Liu A S, Gao J K. Microporous Mesoporous Mater, 2008, 108: 13

[24] Lok B M, Messina C A, Patton R L, Gajek R T, Cannan T R, Flanigen

\section{Graphical Abstract}

Chin. J. Catal., 2014, 35: 1676-1686 doi: 10.1016/S1872-2067(14)60133-9

\section{Investigation of synthesis and hydroisomerization performance of SAPO-11/Beta composite molecular sieve}

Shujin Zhu, Suyao Liu, Huaike Zhang, Enjing Lü, Jie Ren*

Institute of Coal Chemistry, Chinese Academy of Science; University of Chinese Academy of Sciences; Synfuels China Co., Ltd

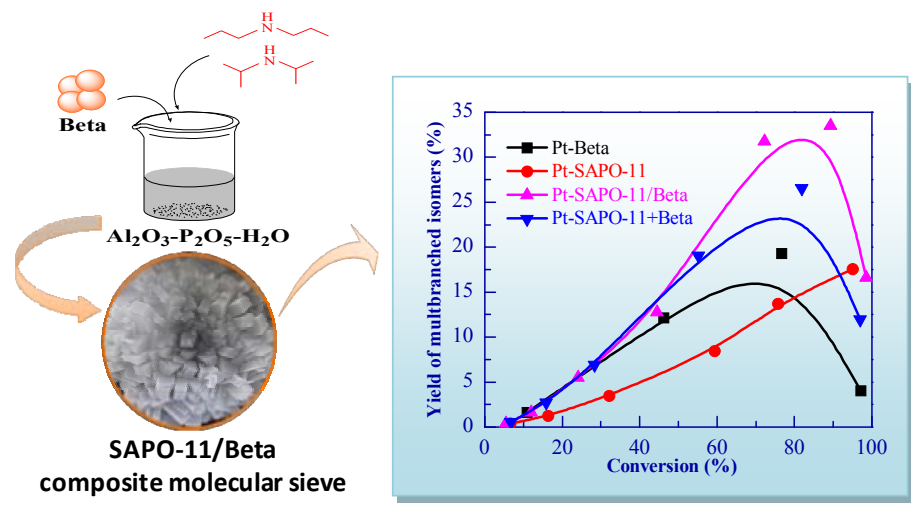

The SAPO-11 (shell)/Beta (core) composite molecular sieve was synthesized using zeolite Beta as the silica source and seed. The Pt-SAPO-11/Beta catalyst gave a higher multibranched isomer yield for the $n$-dodecane hydroisomerization than the mechanically mixed and separate zeolites. 
E M. US Patent 4440871.1984

[25] Liu P, Ren J, Sun Y H. Acta Petrol Sin (Petrol Process Sect) (刘平, 任 杰, 孙予罕. 石油学报(石油加工)), 2008, 24: 388

[26] Gregg S J, Sing K S W. Adsorption, Surface Area and Porosity. 2nd Ed. London: Academic Press, 1982. 154

[27] Li Y P, Pan R L, Huo Q, Zhang W, Dou T, Xie K C. Chin J Inorg Chem (李玉平, 潘瑞丽, 霍全, 张伟, 窦涛, 谢克昌. 无机化学学报), 2005, 21: 1455

[28] Li J, Tan Y S, Zhang Q D, Han Y Z. Fuel, 2010, 89: 3510

[29] Meriaudeau P, Tuan V A, Lefebvre F, Nghiem V T, Naccache C. Microporous Mesoporsous Mater, 1998, 22: 435

[30] Huang X D, Wang L J, Kong L D, Li Q Z. Appl Catal A, 2003, 253: 461

[31] Zhang H Y, Xie B, Meng X J, Müller U, Yilmaz B, Feyen M, Maurer S, Gies H, Tatsumi T, Bao X H, Zhang W P, De Vos D, Xiao F S. Mi- croporous Mesoporous Mater, 2013, 180: 123

[32] Mintova S, Valtchev V, Onfroy T, Marichal C, Knözinger H, Bein T. Microporous Mesoporous Mater, 2006, 90: 237

[33] Li B, Tian P, Qi Y, Zhang L, Xu S T, Su X, Fan D, Liu Z M. Chin J Catal (李冰, 田鹏, 齐越, 张琳, 徐舒涛, 苏雄, 樊栋, 刘中民. 催化学 报), 2013, 34: 593

[34] Zhang Z, Zong B N. Chin J Catal (张哲, 宗保宁. 催化学报), 2003, 24: 856

[35] Huang Y N, Richer R, Kirby C W.J Phys Chem B, 2003. 107:1326

[36] Höchtl M, Jentys A, Vinek H. Catal Today, 2001, 65: 171

[37] Höchtl M, Jentys A, Vinek H. J Catal, 2000, 190: 419

[38] Deng P, Nie C, Li Q Z. J Fudan Univ (Natur Sci Ed) (邓鹏, 聂聪, 李 全芝. 复旦学报(自然科学版)), 2001, 40: 387

[39] Claude M C, Martens J A.J Catal, 2000, 190: 39

\title{
SAPO-11/Beta复合分子篮的合成及其异构化性能研究
}

\author{
朱数金 ${ }^{\mathrm{a}, \mathrm{b}}$ ，刘粟侥 ${ }^{\mathrm{a}, \mathrm{b}}$ ，张怀科 ${ }^{\mathrm{a}, \mathrm{c}}$ ，吕恩静 ${ }^{\mathrm{c}}$ ，任 杰, ${ }^{\mathrm{a}, \mathrm{c}}$, \\ ${ }^{a}$ 中国科学院山西煤炭化学研究所煤转化国家重点实验室, 山西太原030001 \\ ${ }^{\mathrm{b}}$ 中国科学院大学, 北京 100049 \\ c中科合成油技术有限公司煤液化国家能源中心，北京101407
}

\begin{abstract}
摘要: 以Beta分子篎为硅源通过水热合成法合成了SAPO-11/Beta复合分子篮, 采用X射线衍射、 $\mathrm{N}_{2}$ 物理吸脱附、扫描电镜、透视 电镜-能谱分析、固体核磁及吡啶红外等方法对单分子篮、复合分子篮和机械混合分子篮的物化性质进行了表征. 以正十二烷为 模型化合物, 在固定床反应器上考察了铂负载型分子篮催化剂的异构化性能. 结果表明, 复合分子篮的物理化学性质明显不同于 单分子篮和机械混合分子篮, 其呈现核壳结构, SAPO-11和Beta间存在化学作用, 使得复合分子篮具有适宜的B酸分布. 在正十二 烷异构化反应中, 复合分子筛催化剂的异构化性能优于单分子篮催化剂和机械混合分子篮催化剂, 多支链异构体收率高.
\end{abstract}

关键词: SAPO-11; Beta分子篮; 复合分子篎; 核壳结构; 协同作用; 临氢异构化反应; 多支链异构体

收稿日期: 2014-03-07. 接受日期: 2014-04-10. 出版日期: 2014-10-20.

*通讯联系人. 电话: (010)69667806; 传真: (010)69667803; 电子信箱：renjie@sxicc.ac.cn

本文的英文电子版由Elsevier出版社在ScienceDirect上出版(http://www.sciencedirect.com/science/journal/18722067).

\section{1. 前言}

将直链烷烃异构化可提高汽油馏分的辛烷值、降低 柴油馏分的凝点和改善含蜡产品的低温性能. 特别是随 着近年来煤间接液化F-T合成技术在我国实现大规模产 业化, 对其产品异构降凝可生产高品质柴油. 目前, 异构 化反应大多使用分子篮催化剂. Beta ${ }^{[1]}, \mathrm{MOR}^{[2]}$, SAPO-11, SAPO-41和ZSM-22 ${ }^{[3]}$ 分子篮催化剂在烷烃异 构化反应中表现出高的活性和异构选择性. 为了进一步 改善催化剂异构化性能, 双载体催化剂的研究越来越受 到诸多学者的关注 ${ }^{[4-9]}$. Parton等 ${ }^{[10]}$ 采用不同的机械方 法制备了一系列Pt负载的ZSM-22和Y双载体催化剂, 对 ZSM-22和Y分子篮在正癸烷异构反应中协同作用进行 了研究, 并提出了协同作用机理. 孙霞等 ${ }^{[11]}$ 用模型化合 物正十六烷对Beta + SAPO-11机械混合分子笁的异构化 性能进行了研究, 表明由酸性相近的SAPO-11和Beta分 子篮组成的机械混合分子篮催化剂有利于多支链异构 体的形成. 通常机械混合分子篮由于各分子篮间距较
大, 相互间作用不明显. 而化学法合成的复合分子篎除 具有多种分子篮的结构特征外 ${ }^{[12]}$, 分子笁间的强相互作 用使得复合分子篎具有合理分布的酸性、良好的择形催 化性能和水热稳定性, 因此复合分子笁在异构工艺中具 有潜在的应用价值 ${ }^{[13]}$. Liu等 ${ }^{[5]}$ 将水热合成的复合分子 篎( $\beta$-MCM-41)和机械混合分子篎 $(\beta+\mathrm{MCM}-41)$ 用于正 庚烷异构反应研究. 相比于 $\mathrm{Pt} / \mathrm{H} \beta$, 两种双载体催化剂均 表现出更高的异构选择性, 并且复合分子篮催化剂的异 构选择性明显优于机械混合分子篮催化剂.

目前, 关于复合分子篮在长链烷烃异构化性能的研 究较少. 由于不同碳数的正构烷烃在催化剂上的扩散和 反应机理存在较大差异, 因此, 复合分子篮的物理化学 性质对直链烷烃的异构化性能具有较大的影响. Beta分 子笁是一种高硅铝比的大孔硅铝分子篮, 在轻质烷烃异 构化反应中表现出良好的异构性能 ${ }^{[14,15]}$. SAPO-11分子 篮具有温和的酸性和适宜的孔道结构, 在柴油馏分的异 构降凝中比其他分子篮具有更明显的优势 ${ }^{[16-21]}$, 将两者 复合有望在烷烃的异构化反应获得高的催化性能. 
Wang 等 ${ }^{[22]}$ 采用预制晶种法合成了球形的 Beta (core)/SAPO-11 (shell)复合分子笁. Zhang 等 ${ }^{[23]}$ 在弱碱性 条件合成了镶嵌结构的SAPO-11/Beta复合分子篮. 本文 以Beta为硅源在弱酸性条件合成了SAPO-11/Beta核壳 结构的复合分子篮, 并与机械混合分子篮SAPO-11+ Beta进行对比. 通过X-射线衍射、 $\mathrm{N}_{2}$ 吸附-脱附、扫描电 镜、透视电镜-能谱分析、固体核磁和吡啶吸附红外光 谱等手段对SAPO-11/Beta复合分子篮的物理化学性质 进行表征, 并以正十二烷为模型化合物对其异构性能 进行研究.

\section{2. 实验部分}

\section{1. 分子篮的合成}

复合分子篮采用水热法进行合成. 在 $25 \mathrm{~g}$ Beta分子 笁粉末(南开大学催化剂厂, $\left.n\left(\mathrm{SiO}_{2} / \mathrm{Al}_{2} \mathrm{O}_{3}\right)=20\right)$ 中加入 $40 \mathrm{~g}$ 蒸馏水, 调节 $\mathrm{pH}=8.0$, 室温搅拌 $0.5 \mathrm{~h}$; 将拟薄水铝 石 (70 wt \%, 中国铝业) 和正磷酸 $(85 \mathrm{wt} \%$, 国药集团)与蒸 馏水混合, 摚拌 $10 \mathrm{~min}$; 将上述两份浆液混合均匀, 再加 入二正丙胺与二异丙胺(两者的质量比为 $1: 1$, 国药集团) 混合模板剂, 继续摚拌 $0.5 \mathrm{~h}$ 后, 调节 $\mathrm{pH}=6.0$, 倒入 $2 \mathrm{~L}$ 晶 化釜中密封, $200^{\circ} \mathrm{C}$ 晶化 $24 \mathrm{~h}$; 晶化完成后, 经洗涤, $120{ }^{\circ} \mathrm{C}$ 干燥过夜, $550{ }^{\circ} \mathrm{C}$ 焙烧 $15 \mathrm{~h}$ 脱除模板剂得复合分 子篎, 记为 SAPO-11/Beta.

将Beta分子篮(南开大学催化剂厂, $\mathrm{SiO}_{2} / \mathrm{Al}_{2} \mathrm{O}_{3}=20$ ) 和SAPO-11分子篎按质量比 3:17混合均匀制得机械混合 分子笁(记为SAPO-11+Beta). SAPO-11 分子篎按文献 $[24,25]$ 中的水热法合成. 将拟薄水铝石、磷酸和蒸馏水 混合, 搅拌 $10 \mathrm{~min}$, 再依次加入硅溶胶和混合模板剂, 强 烈摚拌 $0.5 \mathrm{~h}$ 混合均匀, 调节 $\mathrm{pH}=6.0$, 将凝胶到入晶化釜 中密封, 其晶化条件和后处理与SAPO-11/Beta相同.

SAPO-11 + Beta和SAPO-11/Beta中SAPO-11的含量 由 XRD 谱图中 SAPO- 11 衍射峰 $2 \theta=23.3^{\circ}$ 峰强度与 SAPO-11含量的标准曲线来确定. 标准曲线由一系列已 知SAPO-11含量的机械混合分子篎的XRD中 SAPO-11 衍射峰 $2 \theta=23.3^{\circ}$ 峰强度所获得.

\section{2. 催化剂的制备}

将分子笁与氧化铝以质量比9:1混合, 加入一定量稀 硝酸, 挤条成型, 制成催化剂载体. 以 $\mathrm{H}_{2} \mathrm{PtCl}_{6}$ 溶液为金 属前驱体, 采用湿式浸渍法负载 $0.5 \mathrm{wt} \% \mathrm{Pt}$, 经 $120^{\circ} \mathrm{C}$ 烘 干, $450{ }^{\circ} \mathrm{C}$ 焙烧 $4 \mathrm{~h}$ 后制得分子笁催化剂.

\section{3. 催化剂的表征}

$\mathrm{XRD}$ 数据采用装有 $\mathrm{Cu}$ 靶 $K_{\alpha}$ 射线光源 $(0.154 \mathrm{~nm})$ 的 Bruker AXS-D8型X射线衍射仪进行采集. 实验条件:
管电压 $30 \mathrm{kV}$, 电流 $10 \mathrm{~mA}$, 扫描步长 $0.02^{\circ}$, 扫描范围 $5^{\circ}-50^{\circ}$. SEM为 FEI公司的Quanta $400 \mathrm{~F}$ 场发射扫描电子 显微镜. 样品的形貌和组成采用备有EDS的Tecnai ${ }^{\mathrm{TM}} \mathrm{G}^{2}$ F30型透视电镜进行表征. 氮气的物理吸脱附实验在 Micromeritics ASAP 2420型物理吸附仪上测定, 样品(大 约 $0.22 \mathrm{~g}$ )在 $350{ }^{\circ} \mathrm{C}$ 真空处理 $8 \mathrm{~h}$. 样品的比表面积和孔容 分别由BET方法和 $t$-plot方法获得. MAS NMR在Bruker 公司的AvanceIII ${ }^{\mathrm{TM}} 600$ 型核磁共振波谱仪上完成, ${ }^{29} \mathrm{Si}$ MAS NMR采用7 mm探头测定, ${ }^{29} \mathrm{Si}$ 的共振频率为 119.2 $\mathrm{MHz}$, 转速为 $5 \mathrm{kHz} .{ }^{27} \mathrm{Al}$ MAS NMR和 ${ }^{31} \mathrm{P}$ MAS NMR均 采用 $4 \mathrm{~mm}$ 探头测定, 转速为 $13 \mathrm{kHz}$, 共振频率分别为 156.4和242.9 MHz. 在Vertex 70型红外光谱仪(Bruker公 司)上测定吡啶吸附的FT-IR. 先将样品磨成细粉, 然后 压制成自撑片置于Harrick公司的原位高温漫反射池 (ZnSe窗片)中密封, 升温至 $400{ }^{\circ} \mathrm{C}$ 保持 $3 \mathrm{~h}$ 抽真空. 然后 在室温下向原位池中通入吡啶蒸气至吸附饱和, 开始升 温, 分别在 150 和 $300{ }^{\circ} \mathrm{C}$ 真空脱附 $1 \mathrm{~h}$, 并测量FT-IR谱.

\section{4. 催化剂性能评价}

催化剂异构性能的评价在连续流动固定床装置上 完成. 在反应之前, $5 \mathrm{ml}$ 催化剂在氢气气氛中 $400{ }^{\circ} \mathrm{C}$ 还原 $4 \mathrm{~h}$. 反应条件: LHSV $=2.0 \mathrm{~h}^{-1}, n\left(\mathrm{H}_{2}\right) / n\left(n-\mathrm{C}_{12}\right)=600, p=$ $2.0 \mathrm{MPa}, t=240-360{ }^{\circ} \mathrm{C}$. 液体产物经冷凝后收集, 由 Agilent 6890N型气相色谱分析, 色谱柱为OV-101毛细管 柱, FID检测器. 气相产物经Agilent 6890N型气相色谱仪 在线分析, 其色谱柱为HP-MoleSieve $5 \mathrm{~A}(30 \mathrm{~m} \times 0.53 \mathrm{~mm})$ 和 HP-Plot $\mathrm{Al}_{2} \mathrm{O}_{3}(30 \mathrm{~m} \times 0.53 \mathrm{~mm})$, 并分别连接 TCD 和 FID检测器. 各催化剂的异构反应的物料平衡均达到 95\%以上. 本文所用到的相关物理量定义如下.

正十二烷的转化率:

Conversion $(\%)=\frac{(n \text {-dodecane })_{\text {feed }}-(n-\text { dodecane })_{\text {effluent }}}{(n \text {-dodecane })_{\text {feed }}} \times 100$

产物 $i$ 组分的收率:

$$
\text { Yield }(\%)=\frac{(i)_{\text {effluent }}}{(n \text {-dodecane })_{\text {feed }}} \times 100
$$

其中, $(n \text {-dodecane })_{\text {feed }}$ 和 $(n \text {-dodecane })_{\text {efflunent }}$ 分别表示原料 和产物中正十二烷的质量浓度. $(i)_{\text {efflunent }}$ 为产物中 $i$ 组分 的质量浓度.

\section{3. 结果与讨论}

\section{1. 催化剂的表征}

\subsubsection{XRD结果}

图 1 为 Beta, SAPO-11/Beta, SAPO- $11+$ Beta 和 SAPO-11 的XRD谱. 由图可见, 复合分子篮中出现了 SAPO-11和Beta分子篎的特征衍射峰, 没有其他杂峰出 
现, 表明SAPO-11/Beta分子笁可以很好的通过水热法合 成. $2 \theta=7.5^{\circ}$ 是Beta分子篎的特征衍射峰, 复合分子篮中 $7.5^{\circ}$ 处衍射峰的峰强度较弱, 表明复合分子篮中Beta分 子篮含量较低. 复合分子篮和机械混合分子篮中SAPO11 质量百分含量见表1.

\subsection{2. $\mathrm{N}_{2}$ 物理吸附结果}

图 2 为 Beta, SAPO-11+Beta, SAPO-11/Beta 和 SAPO- 11 的 $\mathrm{N}_{2}$ 等温吸脱附曲线. 在低压时, 所有样品均 发生单层吸附, 曲线呈现平台, 此为典型的微孔特征 ${ }^{[26]}$. 机械混合分子笁SAPO-11 + Beta和复合分子笁SAPO11 Beta的吸脱附曲线位于单分子篎SAPO-11与Beta的 吸脱附曲线之间, 表明两者是SAPO-11和Beta两种样品 的混合体, 但两者存在较大差异, 由此可知复合分子篮 中Beta和SAPO-11的结合方式不同于机械混合分子篮.

由表1可见, SAPO-11 + Beta和SAPO-11/Beta的比表 面积均介于SAPO-11和Beta分子篮之间, 机械混合分子 篮的比表面积大于复合分子篮. 并且SAPO-11的微孔比 表面积 $\left(144.2 \mathrm{~m}^{2} / 0.85 \mathrm{~g}\right)$ 加上 Beta 的微孔比表面积 $\left(38.6 \mathrm{~m}^{2} / 0.15 \mathrm{~g}\right)$ 等于 $182.8 \mathrm{~m}^{2} / \mathrm{g}$, 此值与复合分子篮 SAPO-11/Beta的微孔比表面积 $\left(180.4 \mathrm{~m}^{2} / \mathrm{g}\right)$ 接近, 表明在 复合分子篮的合成过程中Beta分子篮的孔道没有被新 生成的SAPO-11分子篮所堵塞.

\subsubsection{SEM和TEM-EDS结果}

图 3 为 Beta, SAPO-11, SAPO-11/Beta 和 SAPO-11+ Beta的SEM图. 各分子篮样品的形貌及晶粒大小都存在 明显的差别. Beta分子篎的粒径大约为 $0.4 \sim 0.5 \mu \mathrm{m}$. SAPO-11呈现出规则的正方体形貌, 粒径大小分布均匀, 约为 $4 \mu \mathrm{m}$. 机械混合分子篮SAPO- $11+$ Beta 为 SAPO-11 和Beta简单的混合. 复合分子篮SAPO-11/Beta的形貌为 柱状颗粒堆积的类球形聚集体, 粒径大约 $5 \mu \mathrm{m}$, 没有单 独生长的 Beta和 SAPO-11 分子篮存在. 由此可推测 SAPO-11可能是围绕未溶解的Beta分子篎周围生长的, 形成了以SAPO-11包裹Beta的核壳结构 ${ }^{[27]}$. 相比于机械 混合分子篎, 复合分子篎中SAPO-11和Beta分子篮结合 得更为紧密, 同时, 复合分子笁SAPO-11和Beta分子笁的 晶间空隙结构可形成更多的外比表面积 ${ }^{[28]}$, 这在BET结 果中也得到证实.

SAPO-11/Beta复合分子笁的TEM-EDS分析结果见 图4和表2. 由图4(a)可见, SAPO-11/Beta为长方形材料 致密堆积包裹成类球形颗粒. 通过球形聚集体散落下的 小聚集体(图4(b)) 可以更清晰看到柱状材料的致密镶嵌. 实验中对SAPO-11/Beta进行了EDS能谱分析, 结果见表
2. 复合分子笁SAPO-11/Beta的外层(1\#)硅、磷和铝的分 布与SAPO-11分子篮的类似, 并且其硅铝比不到复合分 子篮的一半, 可以证实复合分子篮是由SAPO-11分子篮 包裹Beta分子篮形成的核壳结构.

\subsubsection{MAS NMR结果}

${ }^{29} \mathrm{Si}$ MAS NMR 的表征结果见图 5 和表 3 . 在 ${ }^{29} \mathrm{Si}$ MAS NMR谱图中, -86 和-91处的谱峰可归属于SAPO区 的 $\mathrm{Si}(0 \mathrm{Si})$ 物种, $-97,-102,-107,-110 /-116$ 处的谱峰分别 归属于 $\mathrm{Si}(1 \mathrm{Si}), \mathrm{Si}(2 \mathrm{Si}), \mathrm{Si}(3 \mathrm{Si})$ 和 $\mathrm{Si}(4 \mathrm{Si})$ 物种 ${ }^{[29-32]}$. 从图 5 中各分子篮的 ${ }^{29} \mathrm{Si}$ MAS NMR可以看出, 复合分子篮 SAPO-11/Beta与机械混合分子篮SAPO-11+Beta中硅所 处的化学环境存在一定差异. SAPO- $11+$ Beta的 ${ }^{29} \mathrm{Si}$ MAS NMR 谱图与Beta分子篎的谱图相似, 这是由于 SAPO-11 分子篮中硅含量低, 导致谱图中 $\mathrm{Si}(n \mathrm{Al})(n=$ 1-3)的谱峰较弱. 复合分子篮SAPO-11/Beta在化学位移 -86 到 -115 间有强弱不等的多重峰. 与SAPO- $11+$ Beta 相比, SAPO-11/Beta中具有较多的 $\operatorname{Si}(n \mathrm{Al})(n=1-3)$ 配位 结构的硅. 由 ${ }^{27} \mathrm{Al}$ MAS NMR 谱图可见, SAPO-11/Beta 和SAPO- $11+$ Beta在 37.5 和 54.5 附近出现谱峰, 分别归属 于SAPO-11和Beta分子篎的骨架四配位铝 ${ }^{[23]}$. 有文献报 导, 微孔磷酸铝材料的四配位铝物种在 40 附近出现共 振峰 ${ }^{[33]}$. 复合分子篮在 40 附近出现三个肩峰, 说明分子 笁中铝配位环境复杂, 这可能是由于SAPO-11和Beta骨 架相互作用形成的晶格缺陷所致. 同时, SAPO-11/Beta 和SAPO- $11+$ Beta在-14处出现一个宽包峰, 可归属于非 骨架六配位铝. 此外, 复合分子篮中非骨架的铝物种明 显多于机械混合分子篎.

图6为 SAPO-11, SAPO-11/Beta和SAPO-11+ Beta的 ${ }^{31}$ P MAS NMR 谱. 由图可见, SAPO-11 和 SAPO-11+ Beta在 -30.7 处均出现骨架四配位磷物种的共振峰 ${ }^{[34]}$. 复合分子篎不仅在 -30.1 处出现一个尖峰, 并且在 -22.5 处出现一个小包峰, 后者可归属于非骨架的磷酸铝相中 的磷物种 $[23,35]$.

\subsection{5. 分子耖酸性结果}

通过Py-IR 对Pt-Beta, Pt-SAPO-11, Pt-SAPO-11 + Beta 和Pt-SAPO-11/Beta催化剂的酸性进行了表征. 由IR谱 图振动峰面积可得到催化剂的酸密度和酸分布, 结果见 表4. 可以看出, 四种催化剂的单位质量总酸量和B酸量 顺序为: Pt-Beta $>$ Pt-SAPO-11+ Beta $>$ Pt-SAPO-11/ Beta $>$ Pt-SAPO-11. $(\mathrm{B}+\mathrm{L})_{150} /(\mathrm{B}+\mathrm{L})_{300}$ 的比值被用于 表征催化剂的强酸和弱酸的分布, 可见, 四种分子篮的 表面均有较多的弱酸. 四种催化剂中 $(\mathrm{B}+\mathrm{L})_{150} /(\mathrm{B}+$ 
L) $)_{300}$ 排列顺序为: Pt-SAPO-11/Beta $>$ Pt-SAPO-11 > Pt-SAPO-11 + Beta $>$ Pt-Beta. 同时, 从催化剂的酸分布 结果可知, 在所有催化剂中, Pt-SAPO-11/Beta具有最高 的 $\mathrm{B}_{150} / \mathrm{L}_{150}, \mathrm{~B}_{300} / \mathrm{L}_{300}$ 和 $\mathrm{B}_{\text {total }} / \mathrm{L}_{\text {total }}$, 即复合分子篮催化剂 具有较高的 $B$ 酸分布.

SAPO-11/Beta复合分子篮出现骨架晶格缺陷位及 骨架外磷酸铝, 表明复合分子篎中SAPO-11和Beta分子 篎的骨架间存在化学作用. 从而导致Pt-SAPO-11/Beta 与 Pt-SAPO-11 + Beta 的酸量和酸分布差异较大. SAPO-11/Beta复合分子篎具有较多 $\operatorname{Si}(n \mathrm{Al})(n=1-3)$ 配位 结构的硅, 因此复合分子篮催化剂表面 $\mathrm{B} / \mathrm{L}$ 酸分布明显 高于单分子篮和机械混合分子篮. 反之, 复合分子篮催 化剂的酸性不同于单分子篮催化剂和机械混合分子篮 催化剂, 也印证复合分子篮中SAPO-11和Beta分子篮间 存在强相互作用.

\section{2. 催化剂的异构化反应性能}

图7为Pt-Beta, Pt-SAPO-11, Pt-SAPO-11 + Beta和 Pt-SAPO-11/Beta催化剂对正十二烷的异构化性能. 由 图可见, 各催化剂上正十二烷转化率大小顺序为: Pt-Beta $>$ Pt-SAPO-11 + Beta > Pt-SAPO-11/Beta > Pt-SAPO-11, 这与它们的总酸量顺序一致 ${ }^{[14,36]}$. 四种催 化剂上正十二烷异构体收率结果见图 8. 由图可见, Pt-SAPO-11/Beta 催化剂具有最高的异构体收率, Pt-SAPO-11 + Beta催化剂的异构体收率介于两种单分 子篮催化剂之间.

Höchtl等 ${ }^{[39]}$ 研究表明, $0.5 \mathrm{wt} \% \mathrm{Pt}$ 负载型双功能催化 剂具有足够的加氢-脱氢活性位. 在加脱氢活性位足够 的催化剂上, 异构反应的控制步骤是烯烃异构体在分子 篮载体 B酸性中心上的异构反应, 催化剂的 B酸中心数 将影响反应异构活性 ${ }^{[8,38]}$. 结合Py-IR结果可见, 异构体 收率随着 $\mathrm{B} / \mathrm{L}$ 的增加而增加, 表明双功能型催化剂中 B酸 分布对正十二烷异构化性能有较大的影响. Pt-SAPO$11 /$ Beta催化剂具有最高的 $B$ 酸密度和 $B_{\text {total }} / L_{\text {total }}$, 因此 Pt-SAPO-11/Beta催化剂获得最高的异构体收率. 在双 载体分子笁催化剂中, Pt-SAPO-11+Beta具有更多的总 酸量, 因此呈现出更高的催化活性, 但是Pt-SAPO-11+ Beta上较多的强酸位 $\left(300{ }^{\circ} \mathrm{C}\right)$ 容易将异构产物进一步裂 解为小分子, 从而使得异构产物收率较低.

Claude 等 ${ }^{[39]}$ 对 Pt/HZMS-22上长链烷烃的临氢异构 化反应进行了研究. 结果表明, 碳数小于 12 的正构烷烃 主要以孔口机理发生异构反应; 而对于碳数大于 12 的正
构烷烃, 锁钥机理成为重要的反应方式. 孔口机理有利 于端甲基异构体在中孔分子篮催化剂上的生成. 由表 5 可知, 正十二烷在Pt-SAPO-11上主要以孔口机理发生反 应. 双载体催化剂 Pt-SAPO-11 + Beta 和 Pt-SAPO-11/ Beta的单支链异构体分布明显不同于单分子篮催化剂, 前者的产物中端甲基异构体含量少, 5-甲基和6-甲基异 构体在单支链异构体中所占比重较大, 因此正十二烷在 双载体催化剂上的异构反应主要通过锁钥机理进行.

图9为不同转化率下Pt-Beta, Pt-SAPO-11, Pt-SAPO11/Beta和Pt-SAPO-11 + Beta催化剂上多支链异构体收 率. 两种双载体催化剂的多支链异构体收率均高于单分 子篮催化剂, 表明复合或混合分子篎中Beta和SAPO-11 在正十二烷的异构化反应中存在协同作用. 这是由于正 十二烷在双载体催化剂上的异构反应主要通过锁钥机 理进行, 即烷烃分子吸附在催化剂的表面, 其两端均可 进入分子篮的孔口内发生异构化反应，从而生成更多的 多支链异构体. 同时还可以看出, 复合分子篮催化剂 Pt-SAPO-11/Beta的多支链异构体明显高于Pt-SAPO-11+ Beta. 前者形成了以SAPO-11包裹Beta的核壳结构, 不同 于 SAPO-11 + Beta 中 SAPO-11 与 Beta的独立结构, 其 SAPO-11与Beta结合更紧密, 锁钥机理发生的概率更大, 有利于生成更多的多支链中间体; 同时, SAPO-11与 Beta分子笁间距小, 多支链异构体的迁移和扩散更容易, 减少了多支链中间体在酸性位上的停留时间, 抑制了裂 解反应的发生. 另一方面, Pt-SAPO-11+Beta中具有较 多的强酸位 $\left(300^{\circ} \mathrm{C}\right)$, 容易将多支链中间体进一步裂解 为小分子. 复合分子篮中 SAPO-11和Beta分子篮间存在 强的相互作用, 具有适宜的B酸酸量和酸分布, 因此具有 更高的多支链异构体收率.

\section{4. 结论}

以Beta为SAPO-11的硅源合成了SAPO-11/Beta复合 分子篎. 复合分子篮中 SAPO-11和Beta间结合紧密, 形 成了较多的 $\operatorname{Si}(n \mathrm{Al})(n=1-3)$ 配位结构的硅和骨架外磷酸 铝, 使得复合分子篮具有较多的弱酸和 $\mathrm{B}$ 酸. 相比于单 分子篮催化剂和机械混合分子篎催化剂, 复合分子篎催 化剂Pt-SAPO-11/Beta在正十二烷异构化反应中获得最 高的多支链异构体收率. 当正十二烷转化率为 $89 \%$ 时, Pt-SAPO-11/Beta的正十二烷多支链异构体收率达到 $34 \%$.

致谢 感谢中科合成油技术有限公司在设备和资金方面对 本研究工作的大力支持. 